\title{
Pictures and Learning Motivation Towards the Eighth Grade Students' Writing Achievement on Descriptive Paragraph
}

\author{
Firdaus \\ Akademi Manajemen Informatika dan Komputer (AMIK) Lembah Dempo Pagaralam \\ Fdaus3261@gmail.com \\ Abstract
}

This research was concerned with an inquiry on the effect of the influence of using pictures and learning motivation towards the eight grades Students writing achievements on the descriptive paragraph of SMP Negeri 6 Pagaralam. The problem of this research was to find out whether or not there was an effect of the application pictures towards student's writing achievement on paragraph descriptive. Pictures strategy is a strategy that provides an opportunity for teachers to model exemplary pre-writing behavior and encourages students to set their purposes for writing. This enables students to become more motivated and active in writing a descriptive paragraph. Data collection employed pre-test and posttest for the experimental group. Data analysis was undertaken by using t-test and ANOVA. Findings showed that there was a significant effect of the application of pictures on student's writing achievement on a descriptive paragraph of the eighth grade of SMP Negeri 6 Pagaralam. The conclusion suggests that Ha was accepted while Ho was rejected. It means that using pictures was effective to improve student's writing achievement in a descriptive paragraph.

Keywords: Pictures, Writing, Descriptive Paragraph, Learning Motivation.

\section{INTRODUCTION}

Language is used as a means to communicate. People speak the language to convey messages, to show their questions, to transfer information, thus, language has a very important role in human life. The one of language used in the word is English. English is an international language, it is the first foreign language taught in Indonesia. In mastering English students must master the four skills; Reading, Speaking, Listening, and Writing.

In writing, the students need to acquire those first to make sure what they want to write. They have to write about what they think in their mind and state it on a paper by using the correct procedure. Writing is one of the important aspects which can influence the students' success in learning English as a foreign language. Through writing, students express or communicate. Besides, Raimes (in Wardani et el, 2014) states "Writing is a skill in which express the ideas, feeling, and thoughts arranged in words, sentences and paragraphs using eyes, brain, and hand." Future more, Wardarita, R. (2014:14) states that "Writing is a form of communication." The students can communicate their ideas and thoughts to others through written from such as letter, message, or invitation for communication.

To enable the students to master in writing, English teachers should provide materials that appropriate with the curriculum and find suitable methods in the teaching-learning process. One of the methods is used picture.

The picture is visual-based learning media. It is known that visual-based media such as pictures can facilitate the understanding of complex or complex subject matter. The pictures media can present an interesting elaboration of the structure or organization of a thing, thus also strengthening the memory. The pictures media can foster student interest and clarify the relationship between the content of learning materials and the real world. To gain the utmost benefit in the use of pictures media in this lesson, it must be designed as well as possible.

Descriptive text is a text that gives information about a particular person, place, or thing. Get et el (in Khairul, 2015:20) state "descriptive text is a kind of text with a purpose to give information." Furthermore, descriptive text is a text which says what a person or a thing is like. Its purpose is to describe and reveal a particular person, place, or thing.

Motivation is the energy that supports students in achieving their needs. The level of motivation influences them to reach those needs. Another important thing in the teaching and learning process is motivation. Harmer (2007:98) states that "Motivation is some kind of internal drives which pushes someone to do things to achieve something." According to Harmer (2007:98)

The motivation is some kinds of internal drives with pushes, someone, to do a thing to achieve something, It is the purpose that determines the level of activity, intensity, consistency, and direction 
common human behavior.

According to Simaibang (2017: 208) "There are two types of learning motivation namely: 1) extrinsic motivation and 2) intrinsic motivation. Both intrinsic and extrinsic motivations come from reward inherent to a task or activity itself." It occurs when people are intrinsically motivated to do something because it either pleases them, they think it is important, or they feel that what they are learning is significant. But the motivation that comes from outside of the performer is called extrinsic motivation. For students, it may come into because factors extrinsic to him or her (like money or good grades).

From the factors above, it is the teachers' responsibility in minimizing the students' failures. Therefore, by applying an appropriate technique in teaching and learning writing. There is some previous study that has been done on the use of using picture technique:

The first previous related study is entitled " The Use of Picture to Teach Writing DescriptiveText to the Eighth Years Students of SMP N 13 Semarang" written by Setya (2007). She found that using pictures technique was effective in improving writing achievement for most of the students with a low score in writing.

The second study is written by Khoirul (2015) entitled " The Use of Picture Prompts to Improve Students, Writing DescriptiveTexts to the Eighth Grade Students of SMPN 1 Bansari, Temanggung". He found that using picture prompts made the students, behavior changed, and improve students writing achievement.

Based on the explanation above, the writer will conduct a study entitled, The Influence of Using Pictures and Learning Motivation toward Writing Achievement on Descriptive Paragraph of Eighth Graders of SMP Negeri 6 Pagaralam.

\section{REVIEW OF LITERATURE}

\section{Concept of Pictures}

The picture is a sketch of an object(s) visualized on a surface of the paper, board, wall, etc. In teaching media, it belongs to the visual aid. According to Wright (1989) Picture as media can motivate students, to make the subject they are dealing with clearer, and to illustrate the general idea and forms of an object or action which are particular to a culture.

According to Mackey (in Eka, 2014:14), "There are three types of pictures." They are thematic pictures, mnemonic pictures, and semantic pictures.

1. Thematic Pictures are those simply to illustrate a theme or a text. Pictures may illustrate the text of the lesson to focus the attention of the learners on what the text says by helping him to image it. Thematic pictures most of coming in the form of crowded scares, illustrating a single theme, like the family leaving in a holiday, the countryside in winter.

2. Mnemonic Pictures are those designed to remind the learner of certain words or sentences, they are conveyed by any sequence of pictures, for example, comic-strip technique.

3. Semantic pictures are those whole solo function is to a specific meaning across. The pictures must contain only what the word means. There must be nothing in the picture except what word means.

By using pictures, the students can be more motivated because pictures provide the real material which can be observed and identified by the students. This is in line with the statement of Wright (in Setya, 2007:9), "Picture can motivate students, and nowadays, motivation is found to be an important factor in learning everything." Pictures are also contextual in which a teacher can draw a certain situation on them. Pictures bring the outside world into the classroom in a concrete way. They can improve students' stimulus because after observing the picture, the students will immediately need the vocabularies, idiom, and sentence structures to discuss or to explain what they see. Writing products that are accompanied by pictures will make the readers more interested. Dils cites Wahyuningsih (2011) says "This is interesting to open a book that is both beautifully illustrated and beautifully written." The harmony between the written and the visual will be able to inspire and entertain the readers. It can be concluded that pictures also contribute to inspiring and entertaining. The picture is one of the visual aids used by the teachers to help to learn. 


\section{Teaching Strategy}

Strategy as an approach to the learning process can be used to support student learning. Strategies are needed so that students can understand the material more easily. Learning strategies are very important in ensuring effective learning and determining the results to be achieved. Furthermore, the teaching strategy is a method used to help students learn the content of the desired subjects and can determine goals that can be achieved in the future. Many strategies can be used in the teaching and learning process. The teacher must choose a strategy that is suitable for students. The appropriate strategy will make the teaching-learning process more effective because the applying of strategy is hoped can motivate and attract the students in studying. In this study the writers using picture word inductive model.

According to Calhoun (in Meiranti 2016:16), "Picture word inductive model is a model that is designed to capitalize on children's ability to think inductive. It means that the process of teaching begins with the explanation and the main idea comes later."

\section{Characteristics of pictures}

According to Wibawa. B. and Mukti, F (1991) states that "A teacher in selecting media should follow the following characteristic:"

1. The suitability of teaching media to be achieved

2. The characteristic of the media must be by the teaching characteristics.

3. The teaching media more sophisticate the development of the student level.

4. suitability of media characteristics with the socio-cultural background.

5. suitability of instructional media with desire, student ability.

6. Teaching media is easy to find and use in schools.

7. Teaching media have good quality, so make the learning process will be achieved.

Desman (2013) states that "The characteristics of pictures are:"

a. It should be authentic, meaning it can describe objects or events as if the students are looking directly.

b. Simply, the composition is quite clear showing the major parts of the picture.

c. The picture size is proportional, so students can easily imagine the actual size of the object or object being drawn.

d. Combine the beauty with suitability to achieve learning objectives.

e. Pictures must be messages, not every good picture is a good medium. As a good medium, the picture should be good from art and by the learning objectives that they wish to achieve.

\section{Concept of Learning Motivation}

Motivation plays an important role in writing. The students will be motivated to write. Harmer (2001) cited Simaibang (2017:207) states " Motivation is some kind of internal drive that encourages somebody to pursue a course of action." Students are strongly motivated by whatever necessary to reach their goals. Harmer (in Simaibang, 2017:209) states " there are two types of motivation." They are 1. extrinsic motivation and 2. intrinsic motivation. Extrinsic motivation is concerned with factors outside the classroom while intrinsic motivation is concerned with what takes place in the classroom. Internal and External factors that stimulate desire and energy in people to be continually interested and committed to learn a subject, or to make an effort to attain a goal are drives that significantly empower people to pursue their lives. Extrinsic motivations are those that arise from outside of the individual and often involve rewards such as trophies, money, social recognition, or praise. Brown ( 2000:76) states that

Defines intrinsic motivation as follows: Intrinsically motivated activities are ones from which there is no apparent reward except the activity itself." People seem to engage in the activities for their own sake and not because they lead to an extrinsic reward. Brown. (2007) states that intrinsic motivation is the reason why we perform certain activities for inherent satisfaction or pleasure; you might say performing one of these activities is reinforcing in-and-of-itself.

\section{Concept of Writing Achievement}

writing is one of the language skills in which the learners should master. According to Simaibang (2017:87), "Writing is categorized under productive skill." Writing is one of the language skills where language learners express or communicate in writing and give a written account of material. At the end of the lesson, the learners are required to produce a written product. Brown 
(2001: 335) states that "Describes written products as the result of thinking, drafting, and revising procedures that require specialized skills, skills that not every speaker develops naturally." That statement shows that writing is not a simple and instant process. Therefore, to be able to write something good, students must do a lot of practice. It is done to get them used to write anything in the well-ordered steps. "There are six steps to creating written work. There are drafting, structuring, reviewing, focusing, generating ideas and evaluation" (Harmer, 2001: 258). Non-creative forms of writing, mostly in essay writing is called the mode of writing. Richards and Schmidt (2002) state that "Classifies modes of writing into four." They are descriptive writing, narrative writing, expository writing, and argumentative writing. In descriptive writing, the learners are required to write a verbal picture or account of a person, place, or thing.

\section{The Process of Writing}

Writing is not merely an instant process. It includes some processes to create a writing product. Harmer (2007:326) states that "The four main stages in writing; they are planning, drafting (writing), revising (redrafting), and editing."

\section{Assessing Writing}

The process of writing involves planning, drafting, revising, and editing. However, those are the process done by the students. To know how well students' works are the teacher makes a judgment about their works. The teacher assesses the students' work by scoring them on a particular scale. Simaibang (2017:91) states that Writing assessment is the student's ability to express their ideas and thought through written texts that cover organization, sentence formation, grammar, vocabulary, mechanics, tidies, and submission deadline.

\section{Concept of Descriptive Paragraph}

Descriptive text is a text that gives information about a particular person, place, or thing. Sulandra (2011) states "Descriptive paragraph is a paragraph which expresses or describes place, thing, and person in such vivid detail that the readers." Descriptive text is a kind of text with a purpose to give information. Furthermore, descriptive text is a text which says what a person or a thing is like. Its purpose is to describe and reveal a particular person, place, or thing. Hartono cites Rosalia (2014:26) states "There are three types of description paragraph." They are descriptions of a place, person, and things.

\section{METHODOLOGY}

This research uses factorial design in the experimental method. According to Fraenkel, et al (2012:277), state that "Factorial Designs extend the number of relationships that may be examined in an experimental study." This method is the modification of the pretest-posttest control group design which permitted the investigation of the moderator variable. Another value of a factorial design is it allows a researcher to study the interaction of an independent variable with one or more other variables, sometimes called moderator variables. Moderator variables may be either treatment variables or subject characteristics variables.

In this study, the writer divided the students into two groups. The experimental group using pictures in the treatment class that is presented into three-way relationships between picture, paragraph content, and writing knowledge. The pictures showed that the students who writing a descriptive paragraph.

The control group uses conventional teaching. The moderator variable of this study is learning motivation. The writer will give pre-test, posttest, and questionnaire on the students' learning motivation. Students' learning motivation would be divided into two motivation levels; high motivation and low motivation based on learning motivation questionnaire scores in the control group and experimental group.

This research was conducted at the Eighth Grade Students at SMP Negeri 6 Pagaralam in the Academic of year 2017/2018 which consist of four class with 88 total number of students. The total number of samples in this research is 60 students. The researcher took the sample by using two stages random sampling used; cluster random sampling and simple random sampling technique. According to Fraenkel and Wallen (2012:91), "It often to combine cluster random sampling with simple random sampling. Cluster random sampling with simple random sampling." Cluster random sampling 
with simple random sampling. "Cluster random sampling is the selection of groups, or cluster or subject rather than individuals is known" (Fraenkel and Wallen, 2012: 96). In the first stage of this study, the writer distributed a questionnaire to all populations. The result of the questionnaires would be classified into two groups, positive and negative motivation. On the second stage, after the cluster random sampling was used to assign the sample, the writer used the sample random sampling. Fraenkel, et al (2012: 91) state that "A sample random sampling is one in which every member of the population has an equal and independent chance of being selected." So, the writer selected a certain number of students randomly by using lottery from each cluster as the experiment and control groups.

\section{Data Collection}

In collecting the data, the writer will use two kinds of instruments. (1) Questionnaire and (2) Writing a descriptive paragraph test.

\section{Pretest and Posttest}

A written test is given in the pretest and posttest form. The pretest is given before doing the treatment (both to experimental and the control group). After giving the pretest to the experimental and control group, the treatment is given to the experimental group only. And then after giving treatment, the writer gives a posttest to an experimental and control group.

\section{Questionnaire}

A questionnaire is any written instrument that presents respondents with a series of questions or statements to which they are to reach either by writing out their answers or selecting from among existing answers (Brown, 2001:6). A questionnaire is a research instrument consisting of a series of questions and other prompts to gather information from the respondent. In this study, the students' writing attainment is the primary source of information. In addition to it, students' views are obtained. The students' views are useful as a means to evaluate the implementation of the experiment, the views of the participants of the experiment. The writer decides to use questionnaires as a means of finding out the problems and view participants.

\section{Data analysis}

\section{Descriptive Statistics}

In descriptive statistics, the students pretest, and posttest score are analyzed through analyzing the descriptive statistics which is displayed in a table. It is done to know the writing scores of students, pretest and posttest in experimental and control groups include the scores of median, modus, standard deviation, standard error of means, minimum and maximum score, range, variance, skewness, standard error of skewness.

\section{Normality Test}

The normality test that will be used in this study aims to know if the population model that is used as the sample of the research for each variable is in the normal distribution or not. Normality test is used to find out if the regression model, dependent and independent variable are normal or not' Although the sample is taken procedurally through sampling procedure, there is still possible that the deviation the standard is extant. Through this analysis, whether the deviation in the measurement of the sample is still normal can be known. Normality test in this study used Kolmogorov - Smirnov from SPSS 20 to see the variables are distributed normally or not with the significance $\alpha=0.05$

\section{Homogeneity Test}

The homogeneity test is used to know whether the sample of the research will be homogeneous or not, and measure the homogeneity used SPPS 20 program for windows and the criteria are: $\mathrm{Ho}$ is accepted if $\mathrm{Sig}>\alpha(0.05)$ or Fcount<Ftable, it means that the data are homogenous.

Homogeneity is used to find out whether or not the samples were in the same variance. To determine whether the students' score is homogeneous or not, the students' posttest scores in the experimental and control groups by using Levene Statistics.

\section{Paired Sample T-test}

The paired sample t-test is commonly used to compare the mean score of sample groups before and after treatment. It is used to analyze significant progress it students writing achievement within experimental and control groups. 


\section{Independent Sample}

T-test Independent sample t-test is used to find out the significant difference in means of two groups. Therefore, it is used to find out the significant difference in mean score between the experimental and control group.

6. Two Way Analysis of Variance

In this study, the writer used an analysis of variance ( Two- Way ANOVA) test to find out whether or not there is an interaction effect of using pictures and learning motivation towards writing achievement.

\section{RESULT AND DISCUSSION}

1. T-test a significant difference in writing achievement on descriptive paragraphs between the eight grade students who have high learning motivation and those who have low learning motivation taught by using pictures of SMP Negeri 6 Pagaralam.

The Independent t-test is the most common to test the significant difference between the students who have high learning motivation and those who have low learning motivation taught by using pictures. It was found that the p-output was 0.000 (Table 3 ). When the poutput was lower than the a significance level 0.05 , this result shows that there was a significant difference in writing achievement between the students who have high learning motivation and those who have low learning motivation taught by using pictures of SMP Negeri 6 Pagaralam. In other words, there was a significant influence of using pictures on writing motivation. So the strategy which was applied to develop students' writing achievement was effective to be taught by using pictures. It is illustrated in Table 3

Table 3.

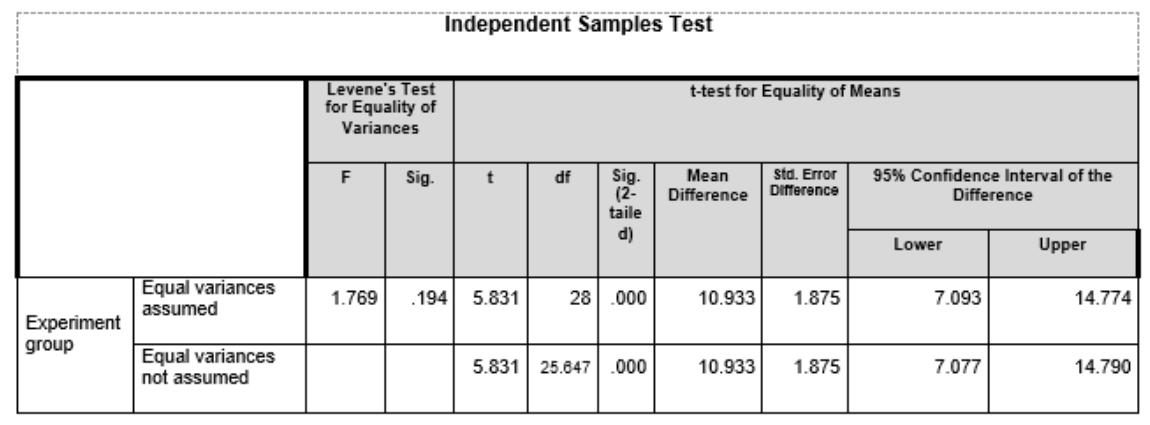

2. T-test the significant difference in writing achievement on descriptive paragraph between the eight grade students who have high learning motivation and those who have low learning motivation taught by using conventional teaching methods of SMP Negeri 6 Pagaralam.

The Independent t-test is the most common to test the significant difference between the students who have high learning motivation and those who have low learning motivation taught by using conventional teaching methods. It was found that the p-output was 0.000 . When the p-output was lower than the a significance level 0.05 , this result shows that there was a significant difference in writing achievement between the students who have high learning motivation and those who have low learning motivation taught by using conventional teaching methods of SMP Negeri 6 Pagaralam. In other words, there was a significant influence of using conventional teaching methods on writing motivation. So the strategy which was applied to develop students' writing achievement was effective to be taught by the conventional teaching method. It is illustrated in Table 4. 
Table 4

Independent Sample Test

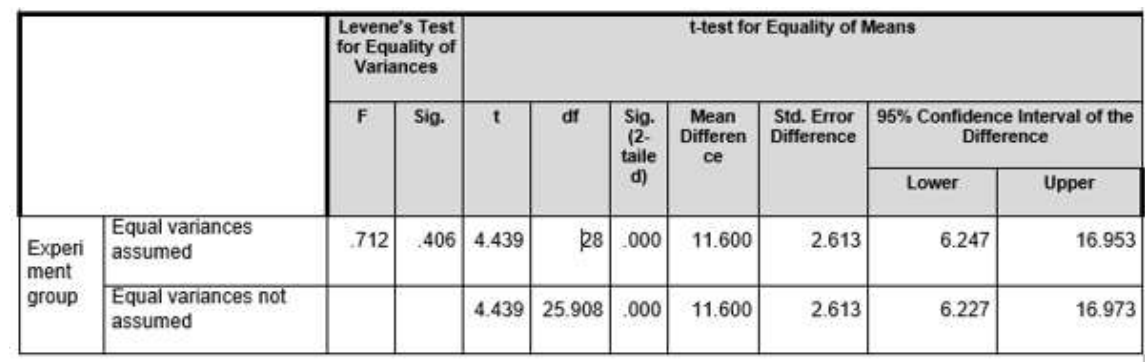

3. T-test the significant difference in writing achievement on a descriptive paragraph for the eighth-grade students who have high learning motivation between those who are taught by using pictures and conventional teaching methods of SMP Negeri 6 Pagaralam.

The Independent t-test is the most common to test the significant difference between the students who have high learning motivation and those who have low learning motivation taught by using pictures and conventional teaching methods. It was found that the p-output was 0.000 . When the p-output was lower than the a significance level 0.05 , this result shows that there was a significant difference in writing achievement between the students who have high learning motivation and those who have low learning motivation taught by using pictures and conventional teaching method of SMP Negeri 6 Pagaralam. So the strategy which was applied to develop students' writing achievement was effective to be taught in both. It is illustrated in Table 5

Table 5

Independent Sample Test

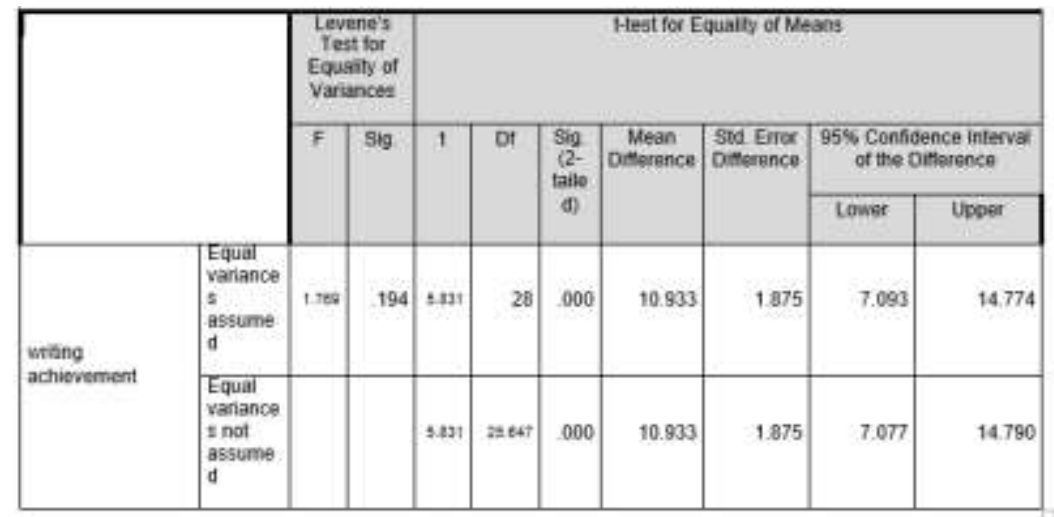

4. T-test the significant difference in writing achievement on a descriptive paragraph for the eighth-grade students who have high learning motivation between those who are taught by using pictures and conventional teaching method of SMP Negeri 6 Pagaralam.

The Independent t-test is the most common to test the significant difference between the students who have high learning motivation and those who have low learning motivation taught by using pictures and conventional teaching methods. It was found that the p-output was 0.000 . When the p-output was lower than the a significance level 0.05 , this result shows that there was a significant difference in writing achievement between the students who have high learning motivation and those who have low learning motivation taught by using pictures and conventional teaching method of SMP Negeri 6 Pagaralam. So the strategy which was applied to develop students' writing achievement was effective to be taught in both. It is 
illustrated in Table 6 .

Table 6.

Independent Samples Test

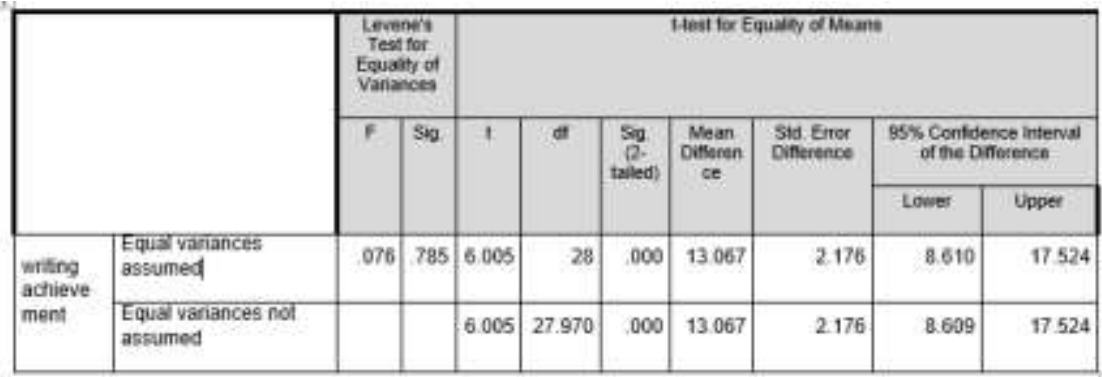

5. T-test the significant interaction effect of using pictures and learning motivation towards the eight grade students writing achievement on descriptive paragraph of SMP Negeri 6 Pagaralam.

In the statistical analyses, the researcher applied two-way ANOVA which is concerned with the investigation of the relationship between one dependent variable (Writing Achievement) and two or more variables (Using Pictures and Learning Motivation). It was necessary to check whether the interaction is significant by checking the significant value. If the value was lower than equal to 0.05 , then there was a significant interaction. From the significant column of Table 7 , it was found that p-output: 0.837 , it is not significant. This finding indicated that there were not any significant interaction effects of using pictures and learning motivation towards the students' writing achievement. It means that there was not any interaction effect of using pictures and learning motivation on students' writing achievement. It is illustrated in Table 7.

Table 7.

Tests of Between-Subjects Effects

\begin{tabular}{|c|c|c|c|c|c|}
\hline \multicolumn{6}{|c|}{ Dependent Variable: Motivasi } \\
\hline Source & $\begin{array}{l}\text { Type III Sum of } \\
\text { Squares }\end{array}$ & Df & Mean Square & $\mathrm{F}$ & Sig. \\
\hline Corrected Model & $4337.800^{\mathrm{a}}$ & 3 & 1445.933 & 37.271 & .000 \\
\hline Intercept & 268001.667 & 1 & 268001.667 & 6908.107 & .000 \\
\hline Motivasi & 1904.067 & 1 & 1904.067 & 49.080 & .000 \\
\hline Pendekatan & 2432.067 & 1 & 2432.067 & 62.690 & .000 \\
\hline $\begin{array}{l}\text { Motivasi * } \\
\text { Pendekatan }\end{array}$ & 1.667 & 1 & 1.667 & .043 & .837 \\
\hline Error & 2172.533 & 56 & 38.795 & & \\
\hline Total & 274512.000 & 60 & & & \\
\hline Corrected Total & 6510.333 & 59 & & & \\
\hline
\end{tabular}

\section{DISCUSSION}

To strengthen the value of this study, there are some results presented in this part based on the calculation of statistics. They are described as follows.

First, t-test analysis of writing achievement between the students who have a high level of motivation and those who have low writing motivation who are taught by using pictures technique. From the statistics calculated using an independent sample test was found the p-output was 0.000 . it means that the p-output was lower than 0.05 it was interpreted that teaching writing using pictures technique was effectively applied in teaching writing descriptive achievement to solve the problem faced by the students. 
Second, t-test analysis of writing achievement between the students who have a high level of motivation and those who have low writing motivation who are taught by using conventional teaching methods. From the statistics calculated using an independent sample test, it was found the p-output was 0.000 , it means that the p-output was lower than 0.05 . It resulted in shows that teaching writing using conventional teaching method was effectively applied in both of the group's students high and low motivation

Third, t-test analysis of writing achievement between using pictures technique and conventional teaching who have high writing motivation. From the statistics calculated using an independent sample test was found the p-output was 0.000 it means that the $p$-output was lower than 0.05 it was interpreted that teaching writing using pictures was effectively applied in the groups of students' high motivation.

Fourth, t-test analysis of writing achievement between using pictures technique and conventional teaching who have low writing motivation. From the statistics calculated using an independent sample test was found the p-output was 0.000 it means that the p-output was lower than 0.05 it was interpreted that teaching writing using pictures was effectively applied in the groups of students with low motivation.

Fifth, t-test analysis by using two - way ANOVA of measuring an interaction effect between the teaching descriptive paragraph by using pictures and conventional teaching that have high motivation and those who have low writing motivation. From the statistics calculated using an independent sample test was found that the p-output was 0.837 it means that the $p$-output was higher than 0.05 , it was interpreted that was not a significant interaction effect of using pictures technique and writing motivation toward students' writing achievement. It means that using pictures and conventional teaching towards learning motivation on writing a descriptive paragraph can be applied both in high and low motivation levels.

\section{CONCLUSION}

In line with the findings above the conclusions are stated as follows:

1. Application of pictures was effective to improve writing achievement on descriptive paragraphs between the eighth-grade students who have high learning motivation and those who have low learning motivation taught by using pictures of SMP Negeri 6 Pagaralam.

2. Application of conventional teaching method was effective to improve writing achievement on descriptive paragraphs between the eighth-grade students who have high learning motivation and those who have low learning motivation taught by using conventional teaching methods of SMP Negeri 6 Pagaralam.

3. Application of pictures and conventional teaching methods were effective to improve the eighth-grade students writing achievement on a descriptive paragraph for the students who have high learning motivation of SMP Negeri 6 Pagaralam.

4. Application of pictures and conventional teaching methods were effective to improve the eighth-grade students writing achievement on a descriptive paragraph for the students who have low learning motivation of SMP Negeri 6 Pagaralam.

5. Application of using pictures and learning motivation did not show interaction effect towards the eighth-grade students writing achievement on descriptive paragraph of SMP Negeri 6 Pagaralam.

\section{REFERENCIES}

Brown, H.D. (2001). Teaching by Principles. New York: Longman.

Brown, L.V. (2007). Psychology of motivation. New York: Nova Publishers.

Eka, S.S. (2014). The influence of Mnemonic pictures and learning motivation toward the eight grade student's reading comprehension achievement of public junior high school 22 Palembang. Palembang: PGRI of University Palembang

Desman. (2013). Penggunaan Media Gambar. http://desmanspdi.blogspot.co.id/2013/10/penggunaan-media-gambar.html 
Fraenkel, J.R, Wallen,N.E, and Hyun, Hellen (2012). How to Design and Evaluate Research in Education. New York: McGraw -Hi Higher Education

Harmer, J. (2007). The Practice of English Language Teaching. New York. Longman.

Khairul, I. Ilmi. (2015). The use of picture prompts to improve students, writing in descriptive texts. Semarang: Universitas Negeri Semarang

Meiranti, W. (2016). The use of Picture Word Inductive Model in developing students Descriptive text Reading ability at the first grade of SMPN 3 Natar Lampung Selatan. Lampung: Universitas Lampung.

Setya, Mei. C. (2007). The use of pictures to teach writing descriptive text. Semarang: Semarang State University.

Simaibang, B. (2017). English Language Teaching in Foreign Situation. Palembang: Citrabooks Indonesia. https://sulandra89.wordpress.com/2011/06/07/33/

Wahyuningsih, A.(2011). Improving students writing skill trough picture media in grade $X$ of office administration 2 of SMK Negeri 1 Tempel: Universitas Yogyakarta. Yogyakarta.

Wardani, I. et al. (2014). Improving the ability in writing Descriptive text trough guide questions technique.E- Journal of English Language Teaching Society Vol. 2 No. 12014 - ISSN 2331 1841.

Wardarita, R (2014) Kemampuan menulis Karya IImiah: Pendekatan Pembelajaran Kontekstual dan Penalaran Verbal.

Wibawa, B. et el. (1991). Media Pengajaran. Jakarta: Departemen Pendidikan dan Kebudayaan Direktorat Jenderal Pendidikan Tinggi Proyek Pembinaan Tenaga Pendidikan.

Wright, A. (1992). Pictures for Language Learning. New York: Cambridge University Press. 